\title{
Les sarcophages en grès du Bourbonnais :
} production, diffusion

Allier et départements limitrophes

Sophie Liegard

\section{OpenEdition}

Journals

Édition électronique

URL : http://journals.openedition.org/adlfi/4744

ISSN : 2114-0502

Éditeur

Ministère de la culture

Référence électronique

Sophie Liegard, «Les sarcophages en grès du Bourbonnais : production, diffusion », ADLFI. Archéologie de la France - Informations [En ligne], Auvergne, mis en ligne le 01 mars 2006, consulté le 21 avril 2019. URL : http://journals.openedition.org/adlfi/4744

Ce document a été généré automatiquement le 21 avril 2019

(c) Ministère de la Culture et de la Communication, CNRS 


\title{
Les sarcophages en grès $\mathrm{du}$ Bourbonnais : production, diffusion
}

\author{
Allier et départements limitrophes
}

\section{Sophie Liegard}

Identifiant de l'opération archéologique : 2004/136 et 2006/122

Date de l'opération : 2006 (PC)

Débuté en 2004, ce PCR a été poursuivi en 2006 (BSR 2004, p. 32-34; BSR 2005, p. 35-36). Cette année a été principalement consacrée à l'avancement des vérifications de terrain, même si celles-ci n'ont pu être aussi importantes que prévu et ce en raison du manque de disponibilité d'une partie des membres du PCR.

2 Les nouvelles données recueillies portent principalement sur les départements de l'Allier et de la Creuse, ainsi que sur les sarcophages conservés au musée Carnavalet à Paris.

3 Par ailleurs, les recherches dans les départements des régions Centre et Bourgogne ont été ralenties et celles envisagées dans les départements rhône-alpins de l'Ain et du Rhône n'ont pu être engagées.

4 En revanche, en ce qui concerne les zones de production du nord de l'Allier, les travaux ont largement progressé. En effet, plusieurs nouvelles carrières ont été découvertes. Deux d'entre elles recèlent même des fragments de cuves et/ou de couvercles de sarcophages qui attestent de manière indiscutable que ces lieux ont bien été exploités durant le haut Moyen Âge pour la fabrication d'éléments funéraires. (Fig. $\mathrm{n}^{\circ} 1$ : Meilliers « Le Taillis-desMoines » : fragment de couvercle de sarcophage abandonné dans une carrière )

5 Au sujet de la définition des zones de diffusion de ces sarcophages, comme cela avait déjà été annoncé précédemment, il s'avère qu'il faudra encore plusieurs années de recherche pour obtenir des résultats exploitables, notamment dans les régions occidentales, septentrionales et orientales. L'équipe du PCR réfléchit donc à la possibilité de créer d'autres PCR dans les régions concernées, afin d'étudier les exemplaires qui y ont été mis 
au jour. Il faut souligner que ces derniers sont assez difficiles à retrouver en raison de l'ancienneté de la majeure partie des découvertes, de la dispersion des sites et de l'absence de chercheurs locaux à même de relayer les vérifications de terrain.

6 Même si les investigations de 2006 ont été limitées, celles-ci ont néanmoins permis d'avancer sur différents points et de recueillir des données inédites qui intéressent directement les problématiques de ce PCR. L'année 2007 devrait permettre d'achever les recherches au moins sur le département de l'Allier, de faire un bilan des acquis de ces quatre années de travaux et de réorienter les investigations sur des secteurs géographiques plus septentrionaux, dont l'étude est primordiale pour la compréhension des phénomènes de diffusion des sarcophages en grès produits dans la zone de bordure septentrionale du Massif central.

\section{ANNEXES}

Fig. $\mathrm{n}^{\circ} 1$ : Meilliers «Le Taillis-des-Moines » : fragment de couvercle de sarcophage abandonné dans une carrière

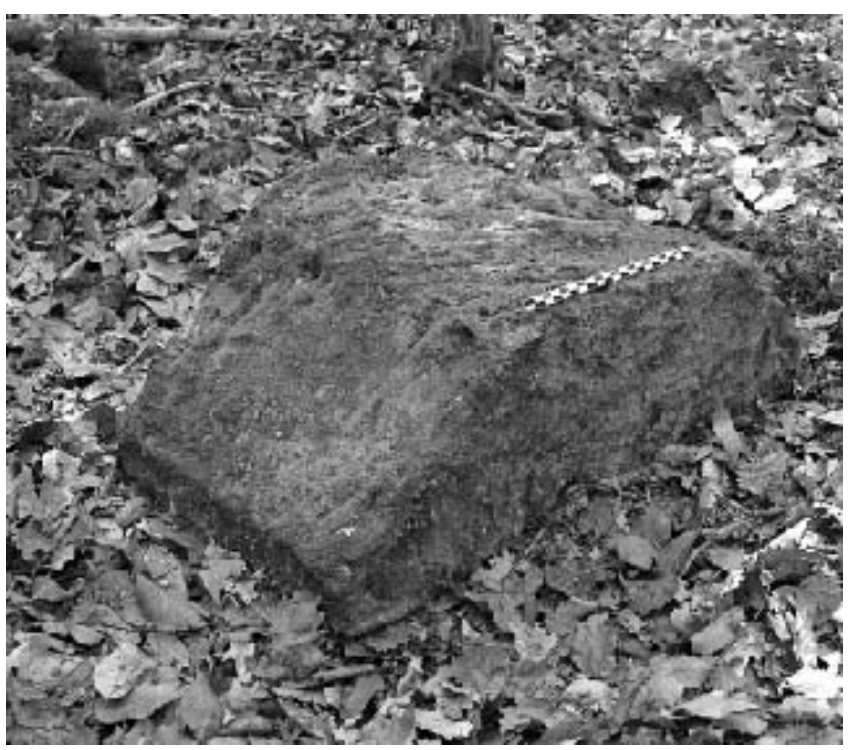

Auteur(s) : Liegard, Sophie (INRAP). Crédits : Liegard Sophie, INRAP (2006)

\section{INDEX}

Index géographique : Auvergne, Allier (03)

Thèmes : carrière, grès, sarcophage

Index chronologique : Moyen Âge

operation Projet collectif de recherche (PCR) 


\section{AUTEURS}

SOPHIE LIEGARD

INRAP 